DOI : https://doi.org/10.3126/njmr.v2i3.26971

\title{
False Belief and Harmful Cultural Practices of Chhaupadi System in Nepal
}

\author{
Dr. Tej Bahadur Karki ${ }^{1} \&$ Kalpana Khadka \\ ${ }^{1}$ Research Expert, Nepal Philosophical Research Center (NPRC), Kathmandu, Nepal \\ ${ }^{2}$ Research Associate, Nepal Philosophical Research Center (NPRC), Kathmandu, Nepal
}

\section{Corresponding Author}

Dr. Tej Bahadur Karki

Email: drtej.karki@gmail.com

\begin{abstract}
Belief system is strongly associated with the socio-cultural practices, family orientation, social environment, schooling of people. Some of the false belief and harmful practices are associated with the Chhaupadi system of Nepal. Chhaupadi is a social tradition related to "menstrual taboo" in the western part of Nepal for Hindu women, which prohibits them from participating in normal family activities during a menstruation period, as they are considered "impure". The main aim of this study is to identify the false belief and harmful cultural practices of Chhaupadi system in Nepal. The study was conducted among the girl students of grade 9 and 10 by using the structured questionnaire survey. The study found that there are many false belief system and harmful cultural practices were associated with Chhaupadi system. The menstrual women were not allowed to enter into the kitchen, not allowed to cook food, not allowed to touch the drinking water, not allowed to enter into the religious places and not allowed to participate in the social functions. The false belief system and harmful cultural practices had negatively affected in the health and hygiene and personal and professional growth and development of women and girls, so such belief system and practices should be removed from the society though the series of orientation and wider level of community discussion.
\end{abstract}

Keywords: Belief, Chhaupadi, Culture, False, Harmful, Nepal, Practices

\section{Introduction}

Chhaupadi is one harmful practice for the society which had directly affected in the personal and professional growth and development of women and girls. Cultural belief on the traditional culture, religious values, and superstition on super-power of God are some major extraneous factors of continuation of Chhaupadi system. The menstrual women and girls have to loss their life also due to snake bite and disease prevalence due to poor hygiene and sanitation of Chhau hut (Karki \& Khadka, 2019). The false belief system harmful cultural practices had negatively affected in the use of knowledge for menstrual hygiene also because they were socially and culturally restricted to touch the most of the things of household as well as free movement in society also. A study conducted among the grade 9 and 10 girl student of Kathmandu valley to identify their knowledge of menstrual hygiene found that the level of knowledge of menstrual 
hygiene was high among the majority (92.5\%) students and majority (56.8\%) got the information from mother about the menstrual hygiene. As well as, $72.5 \%$ girls shared their first menarche with mother (Karki \& Khadka, 2018). When they shared menstrual experience with their mother then the mother teach them about the socio-cultural practices of menstruation. Mother transfer the same knowledge and practices which she has learned and practiced in daily life. Cultural belief system is strongly associated with the menstrual practices. The society has developed some cultural norms for the menstrual women and girls which guides them about their scope of work during the menstrual period. A previous study found that $50 \%$ girls reported that they were deprived to carry out the daily activities like cooking and fetching water and more than $80 \%$ girls shared that they were deprived to go in religious places at the time of menstruation. The result founds that still the cultural practices have created the stigma and discrimination towards the girls at the time of menstruation which has direct effect in their personal and professional growth and development as well as it has also significantly affected in the menstrual hygiene management (Karki \& Khadka, 2019).

The learning knowledge has significant effect in the mind of girls so they perceived such belief system differently as their level of understanding. A previous study conducted to identify the perceived experience of girls at the time of menstrual period which has reported that in total $65 \%$ girls felt less confidence, $80 \%$ felt some kinds of unhealthy feeling, $79.2 \%$ felt uncomfortable to participate in school activities, and $89.2 \%$ girl students felt uncomfortable to participate in social function and festival at the time of menstruation. The study concluded by stating that still girls were mentally and physically suffering at the time of menstruation period whereas menstruation is natural phenomena. So, the study further suggested that the family members and society should be aware themselves first and also encourage the girls to be stress free at the time of menstruation. Harmful traditional belief and practices should be changed for the betterment of social life (Karki, 2018). There was significant effect of such false belief system in educational attainment and achievement of girl students. A study conducted by Dr. Tej Bahadur Karki among the girl students shows that majority (89.2\%) experienced the leaks in school time. As from the observation of facility of school, there was no proper facility for menstrual girl to get the sanitary pad and its safe disposal. So, girls themselves have to manage the sanitary pad. In such condition, $26.7 \%$ said that if they will have leak at school then they will go home, change and stay at home, $25.8 \%$ said that they will go home, change and come back to school and $47.5 \%$ said that they will stay at school if they will have leakage at school (Karki, 2019).

The cultural practice of Nepalese societies is different as the differences in geographical setting, caste groups, religion and educational status. A study was conducted in the Dadeldhura and Kailali district from the qualitative perspective to know the social discourses on practices and remedies of harmful tradition of Chhaupadi. The study has shown that the level of prevalence was decreasing due to regular efforts of Nepal Government and non-governmental organizations through community awareness program though the prevalence of Chhaupadi though it was still high in poor and disadvantage community. The women and girls were facing the physical and mental effect from such practices so study had suggested to abolish such harmful practices from community (Karki \& Khadka, 2019). The above mentioned previous studies have identified and explored the knowledge, practices, perception and social discourses related to menstruation and Chhaupadi system but there is need to explore the experience of girl students of Kathmandu valley towards the false belief and harmful cultural practice of Chhaupadi system in Nepal. 


\section{Materials \& Methods}

The study was conducted in the Kathmandu district among the secondary school's girl students. Basically, student from grade 9 and 10 were selected randomly for the study by using the structured questionnaire survey. The study was based on the descriptive as well as exploratory research design. Data was collected from the cross-sectional design. The collected data was analyzed from the statistical software (SPSS v. 20) and findings are presented in the tabular form.

\section{Results \& Discussions}

Belief system born from the cultural practices of family and society. A belief system is an ideology or set of principles that helps us to interpret our everyday reality. This could be in the form of religion, political affiliation, philosophy, or spirituality, among many other things. These beliefs are shaped and influenced by a number of different factors. Our knowledge on a certain topic, the way we were raised, and even peer pressure from others can help to create and even change our belief systems (Teasley, 2015). The belief system may be barrier for the development of people and society if such belief system is not in favor of people and society as the change of time and social practices. Some superstitious belief and traditional cultural practices may have negate effect in society. Nepal is multi-cultured country so still some of the societies are following the very traditional belief system but such belief system may be false belief and creates the harmful practices in society.

Here, the study had discussed about the false belief and harmful practices of society towards the menstruation and menstrual women and girls. Still society understand that menstruation make women and girls polluted, dirty and untouchable so they were treated accordingly.

\section{Sleep in temporary bed during menstruation period}

Nepal has diverse society having with diverse cultural practices. Some of the western parts of Nepal still have restricted culture for girls during the time of their menstruation period. There is culture of Chhaupadi. Chhaupadi (Nepali: छाउपडी) is a social tradition related to "menstrual taboo" in the western part of Nepal for Hindu women, which prohibits them from participating in normal family activities during a menstruation period, as they are considered "impure". The women are kept out of the house and have to live in cattle shed or a makeshift hut. This period of time lasts between ten and eleven days when an adolescent girl has her first period; thereafter, the duration is between four and seven days each month. During this time, women are forbidden to touch men or even to enter the courtyard of their own homes. They are barred from consuming milk, yogurt, butter, meat, and other nutritious foods, for fear they will forever mar those goods. The women must survive on a diet of dry foods, salt, and rice. They cannot use warm blankets and are allowed only a small rug; most commonly, this is made of jute (also known as burlap). They are also restricted from going to school or performing their daily functions like taking a bath and forced to stay in the conditions of the shed.

The study was conducted in the Kathmandu valley which is the capital city of Nepal so the situation of girls during the time of menstruation is better than western part of Nepal. Though, $47.5 \%$ girls reported that they used to sleep in temporary bed during the time of menstruation 
period. They shared that they used the temporary bed because basically elder people of family asked them to use other bed than their regular bed. It is a cultural practices adopted by the majority of society which is transferring by elder generation to youth.

Table 1: Sleep in temporary bed during menstruation period

\begin{tabular}{|c|c|c|c|c|c|c|c|c|c|c|c|c|c|c|}
\hline & \multicolumn{4}{|c|}{ Type of school } & \multicolumn{4}{|c|}{ Grade } & \multicolumn{4}{|c|}{ Age in Year } & \multirow{3}{*}{$\begin{array}{l}\text { Total } \\
\mathrm{N}\end{array}$} & \multirow[b]{3}{*}{$\%$} \\
\hline & \multicolumn{2}{|c|}{ Public } & \multicolumn{2}{|c|}{ Private } & \multicolumn{2}{|c|}{9.00} & \multicolumn{2}{|c|}{10.00} & \multicolumn{2}{|c|}{$13-15$} & \multicolumn{2}{|c|}{$16-19$} & & \\
\hline & $\mathrm{N}$ & $\%$ & $\mathrm{~N}$ & $\%$ & $\mathrm{~N}$ & $\%$ & $\mathrm{~N}$ & $\%$ & $\mathrm{~N}$ & $\%$ & $\mathrm{~N}$ & $\%$ & & \\
\hline Never & 29 & 48.30 & 34 & 56.70 & 37 & 56.9 & 26 & 47.3 & 41 & 54.7 & 22 & 48.9 & 63 & 52.50 \\
\hline Sometime & 12 & 20.00 & 11 & 18.3 & 13 & 20.0 & 10 & 18 & 16 & 21.3 & 7 & 15.6 & 23 & 19.20 \\
\hline Always & 19 & 31.70 & 15 & 25.00 & 15 & 23.1 & 19 & 34.5 & 18 & 24.0 & 16 & 35.6 & 34 & 28.30 \\
\hline Total & 60 & 100.00 & 60 & 100.00 & 65 & 100.0 & 55 & 100.0 & 75 & 100.0 & 45 & 100.0 & 120 & 100.00 \\
\hline
\end{tabular}

Source: Field Survey 2017

There is very little different found between public (48.3\%) and private (56.7\%) school students who never used the temporary bed for sleep during the time of menstruation period. Furthermore, $54.7 \%$ student of the age 13-15 year and 48.9\% student of the age 16-19 year reported that they never sleep in temporary bed during the period time.

\section{Eating balance diet than other day during menstruation period}

Eating balance diet also depends on the awareness about the need of balance diet, access on dietary products and economic status to afford the cost of balance diet. The students were asked about their dietary habit during the time of menstruation period. In total respondents, $77.5 \%$ said that they used to take the additional diet whereas $22.5 \%$ never took additional diet during the time of menstruation period. Moreover, 29.3\% student of the age 13-15 year and $46.7 \%$ of the age 16-19 year said that they always eat balance diet on the period day compare than other day.

Table 2: Eating balance diet than other day during menstruation period

\begin{tabular}{|c|c|c|c|c|c|c|c|c|c|c|c|c|c|c|}
\hline & \multicolumn{4}{|c|}{ Type of school } & \multicolumn{4}{|c|}{ Grade } & \multicolumn{4}{|c|}{ Age in Year } & \multirow{2}{*}{\multicolumn{2}{|c|}{ Total }} \\
\hline & \multicolumn{2}{|c|}{ Public } & \multicolumn{2}{|c|}{ Private } & \multicolumn{2}{|c|}{9.00} & \multicolumn{2}{|c|}{10.00} & \multicolumn{2}{|c|}{$13-15$} & \multicolumn{2}{|c|}{$16-19$} & & \\
\hline & $\mathrm{N}$ & $\%$ & $\mathrm{~N}$ & $\%$ & $\mathrm{~N}$ & $\%$ & $\mathrm{~N}$ & $\%$ & $\mathrm{~N}$ & $\%$ & $\mathrm{~N}$ & $\%$ & $\mathrm{~N}$ & $\%$ \\
\hline Never & 7 & 11.70 & 20 & 33.30 & 16 & 24.6 & 11 & 20.0 & 21 & 28.0 & 6 & 13.3 & 27 & 22.50 \\
\hline Sometimes & 17 & 28.30 & 33 & 55.00 & 29 & 44.6 & 21 & 38.2 & 32 & 42.7 & 18 & 40.0 & 50 & 41.70 \\
\hline Always & 36 & 60.00 & 7 & 11.70 & 20 & 30.8 & 23 & 41.8 & 22 & 29.3 & 21 & 46.7 & 43 & 35.80 \\
\hline Total & 60 & 100.00 & 60 & 100.00 & 65 & 100.0 & 55 & 100.0 & 75 & 100.0 & 45 & 100.0 & 120 & 100.00 \\
\hline
\end{tabular}

Source: Field Survey 2017

During the time of discussion with girls, they shared that sometimes when they felt more weakness and tried at the time of menstruation then parents used to provide the additional food like fruits and meat whereas in most the day, they ate as usual food. The dietary food habit was different as the economic status and level of awareness of parents. Some of the girls shared that their parents want to provide them additional dietary food at the time of menstruation but due to economic crisis, they could not provide as their interest.

\section{Cultural taboos during the time of menstruation period}

There are certain cultural taboos related to the menstrual women/girls. Nepalese society is dominated by cultural norms and religious ideology so still some cultural practices are in 
functional stage in society. In this connection, perceptual data was collected from the girl students regarding some cultural taboos related to the menstrual women.

In Nepalese society, girls are not allowed to cook food, to enter into the religious place, to participate in rituals, to touch the drinking water and elder male of family. The response shows that in total respondents, $65 \%$ said that restriction in cooking food for family during the time of menstruation is bad practice and $52.9 \%$ said the bad practice of society regarding the restriction to enter into the religious place \& cultural program. Similarly, $76.3 \%$ said that it is bad practice to restrict to touch the elder male people of family and $79.2 \%$ said the bad practice for restriction to touch the drinking water during the time of menstruation period. Furthermore, $80.0 \%$ student of the age 13-15 year reported that it is very practice of not allowing the girls to touch the drinking water during the menstruation period. Moreover, 2.3\% student of the age 16-19 year reported that even touching the elder male people of the family should be given which is a good practice.

Table 3: Cultural taboos during the time of menstruation period

\begin{tabular}{|c|c|c|c|c|c|c|c|c|c|c|c|c|c|c|c|}
\hline \multirow{3}{*}{\multicolumn{2}{|c|}{$\begin{array}{l}\begin{array}{l}\text { Girls should not be } \\
\text { allowed }\end{array} \\
\ldots \ldots \ldots \ldots \ldots \ldots \text { during } \\
\text { menstruation period }\end{array}$}} & \multicolumn{4}{|c|}{ Types of school } & \multicolumn{4}{|c|}{ Grade } & \multicolumn{4}{|c|}{ Age in Year } & \multirow{2}{*}{\multicolumn{2}{|c|}{ Total }} \\
\hline & & \multicolumn{2}{|c|}{ Public } & \multicolumn{2}{|c|}{ Private } & \multicolumn{2}{|c|}{9.00} & \multicolumn{2}{|c|}{10.00} & \multicolumn{2}{|c|}{$13-15$} & \multicolumn{2}{|c|}{ 16-19 } & & \\
\hline & & $\mathrm{N}$ & $\%$ & $\mathrm{~N}$ & $\%$ & $\mathrm{~N}$ & $\%$ & $\mathrm{~N}$ & $\%$ & $\mathrm{~N}$ & $\%$ & $\mathrm{~N}$ & $\%$ & $\mathrm{~N}$ & $\%$ \\
\hline \multirow{3}{*}{$\begin{array}{l}\text { Cooking } \\
\text { food }\end{array}$} & $\begin{array}{l}\text { Good } \\
\text { Practice }\end{array}$ & 9 & 15 & 11 & 18.3 & 7 & 10.8 & 13 & 23.6 & 10 & 13.3 & 10 & 22.2 & 20 & 16.7 \\
\hline & $\begin{array}{l}\text { Bad } \\
\text { Practice }\end{array}$ & 35 & 58.3 & 43 & 71.7 & 47 & 72.3 & 31 & 56.4 & 53 & 70.7 & 25 & 55.6 & 78 & 65 \\
\hline & & 16 & 26.7 & 6 & 10 & 11 & 16.9 & 11 & 20.0 & 12 & 16.0 & 10 & 22.2 & 22 & 18.3 \\
\hline \multirow{3}{*}{$\begin{array}{l}\text { Enter into } \\
\text { the } \\
\text { religious } \\
\text { place \& } \\
\text { cultural } \\
\text { program }\end{array}$} & $\begin{array}{l}\text { Good } \\
\text { Practice }\end{array}$ & 11 & 18.3 & 22 & 37.3 & 23 & 35.4 & 10 & 18.2 & 26 & 34.7 & 7 & 15.6 & 33 & 27.7 \\
\hline & $\begin{array}{l}\text { Bad } \\
\text { Practice }\end{array}$ & 32 & 53.3 & 31 & 52.5 & 32 & 49.2 & 32 & $58 ?$ & 37 & 49.3 & 27 & 60.0 & 63 & 52.9 \\
\hline & $\begin{array}{l}\text { Don't } \\
\text { Know }\end{array}$ & 17 & 28.3 & 6 & 10.2 & 10 & 15.4 & 13 & 23.6 & 12 & 16.0 & 11 & 24.4 & 23 & 19.3 \\
\hline \multirow{3}{*}{$\begin{array}{l}\text { Touch the } \\
\text { elder male } \\
\text { people of } \\
\text { family }\end{array}$} & $\begin{array}{l}\text { Good } \\
\text { Practice }\end{array}$ & 2 & 3.4 & 5 & 8.5 & 4 & 6.2 & 3 & 5.6 & 6 & 8.0 & 1 & 2.3 & 7 & 5.9 \\
\hline & $\begin{array}{l}\text { Bad } \\
\text { Practice }\end{array}$ & 43 & 72.9 & 47 & 79.7 & 55 & 84.6 & 36 & 66.7 & 62 & 82.7 & 29 & 65.9 & 90 & 76.3 \\
\hline & $\begin{array}{l}\text { Don't } \\
\text { Know }\end{array}$ & 15 & 23.7 & 8 & 11.9 & 6 & 9.2 & 15 & 27.8 & 7 & 9.3 & 14 & 31.8 & 23 & 17.8 \\
\hline \multirow{4}{*}{$\begin{array}{l}\text { Touch the } \\
\text { drinking } \\
\text { water }\end{array}$} & $\begin{array}{l}\text { Good } \\
\text { Practice }\end{array}$ & 7 & 11.7 & 6 & 10 & 5 & 7.7 & 8 & 14.5 & 8 & 10.7 & 5 & 11.1 & 13 & 10.8 \\
\hline & $\begin{array}{l}\text { Bad } \\
\text { Practice }\end{array}$ & 47 & 78.3 & 48 & 80 & 54 & 83.1 & 41 & 74.5 & 60 & 80.0 & 35 & 77.8 & 95 & 79.2 \\
\hline & $\begin{array}{l}\text { Don't } \\
\text { Know }\end{array}$ & 6 & 10 & 6 & 10 & 6 & 9.2 & 6 & 10.9 & 7 & 9.3 & 5 & 11.1 & 12 & 10 \\
\hline & Total & 60 & 100 & 60 & 100 & 65 & 100.0 & 55 & 100.0 & 75 & 100.0 & 45 & 100.0 & 120 & 100 \\
\hline
\end{tabular}

Source: Field Survey 2017

The Government law alone may not be adequate to abolish such harmful practices so it needs the realization about the superstition of Chhaupadi and its negative consequences in social development and change, as well as commitment from the community to abolish such practices. Government and non-governmental organizations should include such types of harmful practices 
of society as a cross-cutting issues in all types of social awareness programs to sensitize the people. Educational and economic empowerment may be the effective way to control such harmful practices.

\section{Conclusion}

The cultural practices of menstruation have developed the false belief system and harmful traditional practices towards the menstrual women and girls. The study found that still menstrual women and girls sleeps in separate bed at the time of menstruation. Very rare family who have good economic status and aware on menstruation, are providing additional dietary food to menstrual women and girls. Majority girl students shared that there were bad practices in their community that menstrual women were not allowed to enter into the kitchen, not allowed to cook food, not allowed to touch the drinking water, not allowed to enter into the religious places and not allowed to participate in the social functions. The false belief system and harmful cultural practices had negatively affected in the health and hygiene and personal and professional growth and development of women and girls, so such belief system and practices should be removed from the society though the series of orientation and wider level of community discussion.

\section{References}

Karki, D. T. ( 2018, December). Perceived Experience of Girls at the Time of Menstrual Period: A Study of School Student of Kathmandu, Nepal. Nepal Journal of Multidisciplinary Research (NJMR), 1(2), 9-16.

Karki, D. T. (2019). Menstrual Effect on Education of Girl Student: Cases from Secondary Level School of Kathmandu, Nepal. World Wide Journal of Multidisciplinary Research and Development, 5(1), 6669.

Karki, D. T., \& Khadka, K. ( 2018, September). Knowledge of Menstrual Hygiene among the Girl Students of Secondary Level School of Kathmandu Valley. Nepal Journal of Multidisciplinary Research (NJMR), 1(1), 22-29.

Karki, D. T., \& Khadka, K. (2019, March ). Social Discourses on Practices and Remedies of Harmful Tradition of Chhaupadi in Far Western Region of Nepal. Nepal Journal of Multidisciplinary Research (NJMR), 1-6.

Karki, D. T., \& Khadka, M. K. ( 2019, June). Cultural Barrier at the time of Menstruation: Perspective from Girl Student. Nepal Journal of Multidisciplinary Research (NJMR), 2(2), 16-20.

Teasley, D. (2015, Feb 7). AP World History: Tutoring Solution / History Courses. Retrieved November 19, 2019, from The Study.com: https://study.com/academy/lesson/belief-systems-definition-typesquiz.html\#transcriptHeader 